\title{
TECHNOLOGICAL PROPERTIES OF FLOUR AND THEIR EFFECT ON QUALITY INDICATORS OF SUGAR COOKIES
}

\author{
Tatyana V. Savenkova, Elena A. Soldatova*, Svetlana Yu. Misteneva, Mikhail A. Taleysnik \\ All-Russian Scientific Research Institute of Confectionery Industry - Branch of V.M. Gorbatov Federal Research Center \\ for Food Systems of RAS, Moscow, Russia
}

KEY WORDS:

wheat flour, technological properties, sugar cookies, rheological properties, organoleptic characteristics

\begin{abstract}
The main recipe component of most types of flour confectionery is wheat flour, the technological properties of which largely effect not only the quality indicators of the finished product, but also the stability of the technological flow of its production. However, today, in Russia there are no specialized requirements for the quality of wheat flour for confectionery, in contrast to the requirements for the baking wheat flour. The article lists the main problems and features of the quality of Russian wheat flour consisting in the absence of target classifications of grain and a decrease in its qualitative potential, in particular, a decrease in the amount of gluten and improvement of its quality. As part of the work, the influence of the technological properties of wheat flour on the rheological parameters of the dough and the quality of sugar cookies, which are traditionally in high demand of population groups of every age, was studied, while the share of domestic products is more than $85 \%$. The work was performed in the laboratory of flour confectionery products of All-Russian Scientific Research Institute of Confectionery Industry. The determination of organoleptic, physical and chemical, structural and mechanical indicators of raw materials, semi-finished products and finished products was carried out by standard methods.
\end{abstract}

\section{Introduction}

The Russian confectionery market is one of the largest, being second in kind only to the US market. Data analysis on the consumer market in Russia shows that confectionery products are products of daily demand that are popular with all segments of the population, which is explained not only by the special taste of the product, but also by its positive emotional impact on people $[1,2]$.

The number of confectionery products manufactured in Russia is growing, and so is their consumption [3,4] (Figure 1).

Despite the positive moments, the industry has two acute problems: equipment wear, amounting to about $50 \%$, and the lack of available and high-quality raw materials $[5,6]$.

The success of food producers lies in solving difficult problems: on the one hand, it is necessary to achieve stable quality of products, and on the other hand - technological processes and recipe components are subject to changes due to a number of reasons, in particular, of their natural origin $[7,8]$.

It is possible to minimize risks by determining the quality indicators of raw materials specific for each particular type of products ensuring the production of stable quality finished products [9].

The main component of the flour confectionery recipes is wheat flour, it has a significant impact on the properties of the dough, the quality and manufacturability of finished products. The existing range of flour confectionery products is wide and diverse (more than 1000 items). The permanent favorite is the cookies group, which occupies about $53 \%$ of the total production of flour confectionery products, whereas the share of domestic products is more than $85 \%$ (Figure 2).

An acute problem of the industry is the lack of specialized requirements for the quality of wheat flour for confectionery, in contrary to the requirements for baking wheat flour $[10,11,12]$. Given that, the requirements for the technological properties of flour depending on its purpose are significantly different. The solution of this issue will allow more efficient use of grain resources, rationalize the process of production of flour confectionery products and stabilize their quality.

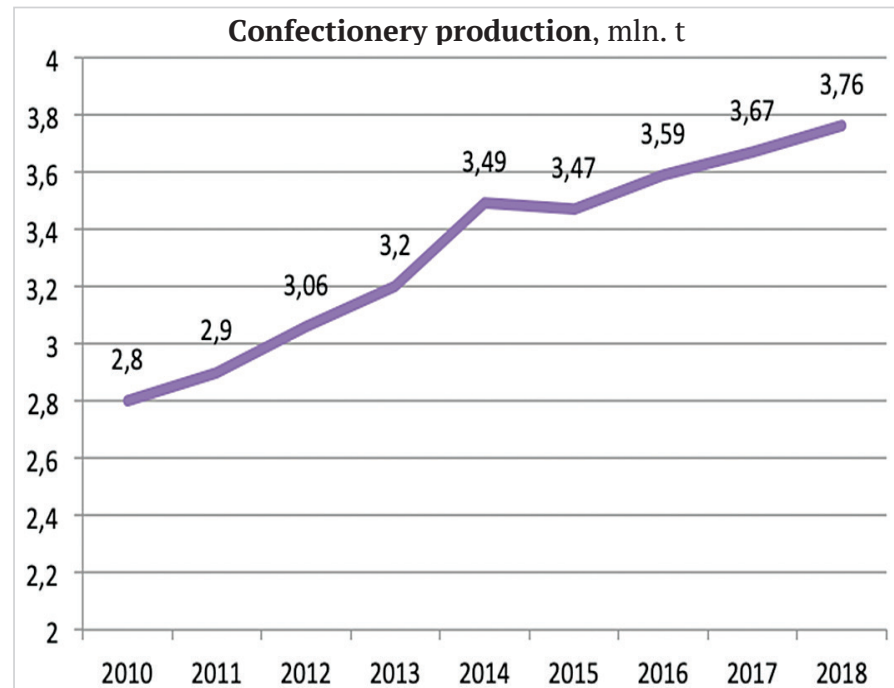

Consumption of sweets, $\mathrm{kg} /$ pers. per year

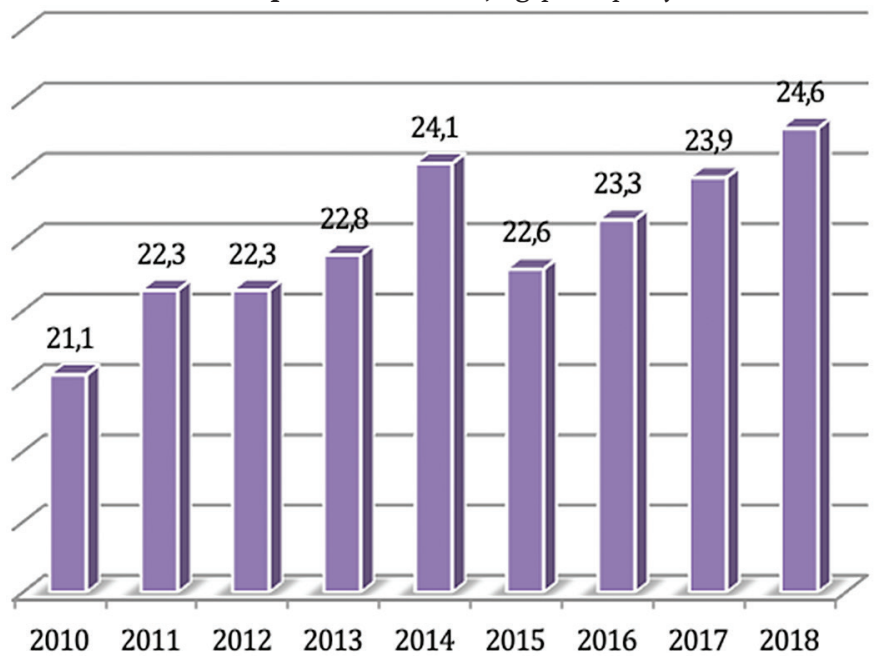

Figure 1. Dynamics of confectionery production in 2010-2018 


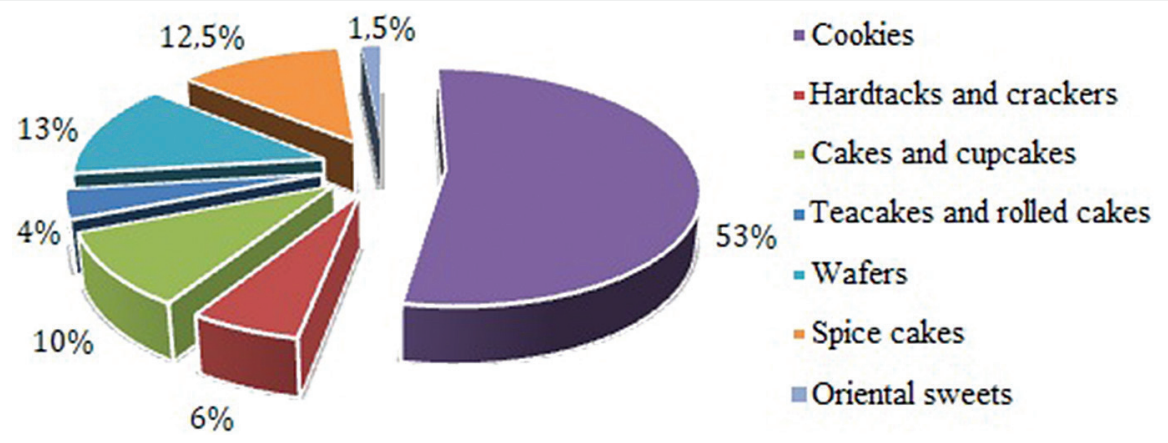

Figure 2. Ratio of products in the group of flour confectionery

The purpose of this work is to analyze the technological properties of wheat flour and the establishment of patterns of their influence on the rheological characteristics of the dough and the quality of sugar cookies.

\section{Materials and methods}

The objects of the study were samples of wheat flour of the highest grade, characterized by a wide range of basic standardized quality indicators. Samples of dough and finished products (sugar cookies) prepared according to the classic recipe and traditional technology. The determination of organoleptic, physical and chemical, structural and mechanical indicators of raw materials, semi-finished products and finished products was carried out by standard methods. Organoleptic characteristics of finished products according to GOST 24901-89 and GOST 5897-90; mass fraction of moisture - by drying the sample in a drying cabinet according to GOST 5900-73; wettability of cookies - by increasing the mass of the product, when immersed in water at a temperature of $20^{\circ} \mathrm{C}$ for a certain time (2 minutes) according to GOST 10114-80. Wettability depends on the porosity of products, characterized by the ratio of the mass of products after wetting to the mass of dry products and is expressed as a percentage. Water activity was determined using an AquaLab 4TE analyzer (Decagon Devices, USA) by the mirror-cooled dew point sensor method; the plastic strength of the cookies was determined using the device KP-3 of professor Volarovich. Water absorbing ability and rheological properties of flour were determined using the Brabender farinograph WP 810101 according to GOST ISO 5530-1-2013.

Mathematical processing of experimental data was carried out by the descriptive statistics method.

\section{Results and discussion}

Depending on the type, flour confectionery products differ significantly from each other not only by the appearance and taste characteristics but also by the recipe composition, production technology, structural and mechanical properties of the dough, the texture of the finished products, etc. The key to the stability of quality indicators of finished products is a differentiated approach to the technological properties of the main raw material in the production of specific groups of products $[7,13,14]$.

Main raw materials for the production of sugar cookies are: wheat flour (more than 50\%), sugar (15-35\%) and fatty component (5-30\%) [15]. Recipe and technological features of the dough: high content of sugar and fat, low moisture limit the swelling of gluten proteins of the flour and help to obtain a plastic consistency of the dough, which makes it possible to apply complex patterns on the surface of the blanks upon molding. The study of the rheological properties of the dough is very important for understanding the changes occurring in the dough at the stages of kneading and molding, which provides the quality control of the products $[16,17,18]$.
The flour significantly effects the rheological properties of the dough, the structure, hardness and shape of sugar cookies. Abroad, the question about the choice of flour with properties that are optimal for each type of product is solved at flour mills.

In Europe, the USA and Canada, the requirements for flour are strictly differentiated: for sugar cookies and biscuits - with a low content of protein, for bakery products - with a high content of gluten $[19,20]$.

In the USA, the commodity classification of grain already provides for the intended use of wheat depending on its type (Table 1 and Table 2).

Classification of wheat in the USA

Table 1

\begin{tabular}{clll}
\hline & \multicolumn{2}{c}{ Type name } & \multicolumn{1}{c}{ Wheat purpose } \\
\hline I & Durum & Hard (durum) & Pasta production \\
\hline II & Hard Red Spring & Hard red spring grain & Bakery, pasta production \\
\hline III & Hard Red Winter & Hard red winter grain & Bakery \\
\hline IV & Soft Red Winter & Soft red winter grain & Confectionery production \\
\hline V & Hard White & Hard white grain & $\begin{array}{l}\text { Bakery and confectionery } \\
\text { production }\end{array}$ \\
\hline VI & Soft White & Soft white grain & Confectionery production \\
\hline
\end{tabular}

Table 2

Requirements for specialized flours in the USA

\begin{tabular}{lcccc}
\hline $\begin{array}{c}\text { Flour for } \\
\text { production of }\end{array}$ & $\begin{array}{c}\text { Ash } \\
\text { content, \% }\end{array}$ & $\begin{array}{c}\text { Protein } \\
\text { content, \% }\end{array}$ & $\begin{array}{c}\text { Gluten } \\
\text { quality }\end{array}$ & $\begin{array}{c}\text { Flour } \\
\text { particle size, } \\
\text { microns }\end{array}$ \\
\hline Bread & 0.50 & $11.5-14.0$ & Strong & 50 \\
\hline Cookies & 0.44 & $8.0-9.5$ & Weak & $30-45$ \\
\hline Cakes & 0.44 & $8.5-9.5$ & The same & $30-50$ \\
\hline Cupcakes & 0.36 & 8.5 & Relatively strong & 30 \\
\hline Crackers & 0.43 & $9.5-11.0$ & The same & $35-50$ \\
\hline Biscuits & 0.40 & $8.0-10.5$ & The same & $30-45$
\end{tabular}

In the USA, despite the vast area of wheat cultivation, due to the favorable conditions for growing this crop - mild winter, warm spring, hot summer with sufficient amount and time of rainfall, stable weather for years, minimal damage by insects and diseases, no corn-bug, etc. - the grain yields obtained are of relatively constant quality. The American standard is significantly different from the Russian one, it contains a division into types of wheat of the species Triticum aestivum (common wheat), which takes into account such important genetically inherited characteristic of grain as hardness of grain characterizing a variety not only by its structural and mechanical properties, but also by its intended purpose [11,19,20,21].

In Russia, due to the huge diversity of soil and climatic conditions, sharp fluctuations of weather conditions over the years, as well as damage by insects (especially corn-bug), the resulting grain yields are characterized by a wide range of quality indicators. In 
particular, with the same protein content there can be completely different gluten content of different quality (according to the AllRussian Scientific and Research Institute for Grain and Products of its Processing data in Russian wheat from different growing regions under different agro-conditions, the ratio between protein and gluten ranges from $0.4: 1$ to $2.4: 1$, while due to the relative constancy of the quality of grain in the USA, this ratio is subject to less fluctuation and is approximately $2.36: 1$ ). The term «soft» wheat used in the Russian standard is conditional and does not give an accurate assessment of the grain hardness, which leads to the fact that varieties with genetically different traits characterizing the difference in their technological properties are not separated and relate to the same type. According to the classification of the Russian standard, among the wheat grains of each type there can be both vitreous (solid grain) and powdery (soft grain) varieties. In fact, in Russia, the overwhelming majority of wheat varieties included in the state register and relating to the species Triticum aestivum are hard grain, and only a very small number of varieties are soft grain. At the same time, unlike the American standard, in which such wheat is divided into separate types - soft grain («soft»), in the Russian standard, the available soft grain varieties are not identified in a separate type [11,19,20,21].

Unfortunately, the current trend of the grain market in Russia is the decline in the quality of flour produced, the main rea- sons for which are: lack of target grain classifications; reduction in the quality potential of wheat, and as a result, a decrease in the quantity and strengthening of gluten; high drop numbers; sprouted grain; damage by corn-bug; dry wind grain; frost damaged grain $[21,22]$.

This situation leads to the fact that wheat flour produced in Russia, used for the flour confectionery, is characterized by a very wide range of quality indicators and, accordingly, has different technological properties. It adversely affects the stability of the quality indicators of finished products and their production technology, causing the situation when same product prepared according to the same recipe and technology, using the same name and type of flour, often has a different quality [12,23].

In general, the main patterns of influence of wheat flour indicators on the quality characteristics of sugar cookies are presented in Table 3.

In order to establish the determining characteristics of the wheat flour quality, which most fully reflect the technological properties of flour that are optimal for sugar cookies, studies have been carried out using samples of wheat flour of the highest grade from three manufacturers (widely represented on the raw materials market).

The quantitative severity of the indicators is presented in Table 4 and Table 5.

Table 3

Main patterns of influence of wheat flour indicators on the quality characteristics of the dough and sugar cookies

Indicator Characteristic Patterns of influence

Amount and quality Protein content is less than 9.0\%. When using flour with a low content of protein, extra crumbly cookies are obtained, and when of protein (gluten) Gluten content $22-26 \%$ using flour with a high content of protein, the result is hard and coarse structure.

With an increase in the ash content, the amount of bran increases, the flour becomes much darker, and its water absorption capacity increases. This leads to the need to increase the moisture of the dough, can provoke the spreading of the blanks in the baking process and their excessive sticking to the oven ribbon, as well as the grayish tint of the cookies.

The amount of water used to prepare the dough should be minimal, since the finished product should be almost completely dry, in addition, reducing the amount of water in the dough leads to energy savings when baking.

The amount of water that the flour

Water

absorption index absorbs when forming a dough of a normal consistency, mixed with 100 $\mathrm{g}$ of flour, is no more than $155 \mathrm{ml}$.

Flour particle size

Not less than $60 \%$ of particles with a size of about 50 microns

The content of protein, damaged starch grains and cellulose in the flour have a significant impact on this index.

In this regard, it is advisable to use flour with a low water absorption capacity and, consequently, low protein content, fiber, weak gluten and slight damage to starch.

The smaller the particle size of the flour, the greater their total surface and, consequently, the higher water absorption capacity.

The protein content also depends on the particle size of the flour: particles up to 15 microns in size contain protein twice as high as in the original flour, particles from 15 to 40 microns are rich in medium-sized starch grains with a small amount of protein (50-66\%). In particles larger than 40 microns, the protein level is the same as in the original flour

Finer flour for the sugar dough gives lower density cookies, greater growth during baking and less spreadability on the ribbon.

Moisture $\quad$ Not more than $14.5 \%$

The storage capacity of flour with a moisture content of more than $14.5 \%$ decreases due to the growth of mold, it does not mix well through the pipeline, it forms vaults in bins and dispensers.

- 2.5-3.0 deg. for top-grade wheat

flour
$-3.0-3.5 \mathrm{deg}$. for top-grade wheat

Flour acidity flour Grade I

Determines the freshness of the flour, its numerical value increases with storage time. High acidity negatively affects the storage capacity of products, the product from it quickly becomes rancid, it has an unpleasant taste and odor.

Quality characteristics of wheat flour samples

\begin{tabular}{|c|c|c|c|c|c|c|}
\hline \multirow{2}{*}{ No. } & \multirow{2}{*}{ Indicator name } & \multirow{2}{*}{ UOM } & \multicolumn{3}{|c|}{ VALUE } & \multirow{2}{*}{ SD for test methods } \\
\hline & & & Sample No.1 & Sample No.2 & Sample No.3 & \\
\hline 1 & Color & - & \multicolumn{3}{|c|}{ White with creamy tint } & GOST $27558-87$ \\
\hline 2 & Whiteness & $\begin{array}{l}\text { Conv. unit of the } \\
\text { device RZ-BPL-Ts }\end{array}$ & 62.0 & 55.0 & 59.0 & GOST 26361-2013 \\
\hline 3 & Moisture content & $\%$ & 13.7 & 13.2 & 12.6 & GOST 9404-88 \\
\hline 4 & Mass fraction of protein & $\%$ & 11.5 & 11.7 & 12.1 & GOST 10846-91 \\
\hline 5 & Mass fraction of raw gluten & $\%$ & 25.0 & 26.0 & 28.0 & GOST 27839-2013 \\
\hline 6 & Raw gluten quality & UOM & $\begin{array}{l}65 \\
\text { Group I }\end{array}$ & $\begin{array}{l}70 \\
\text { Group I }\end{array}$ & $\begin{array}{c}51 \\
\text { Group II (satisfactory strong) }\end{array}$ & GOST 27839-2013 \\
\hline 7 & $\begin{array}{l}\text { Grind size, residue according to GOST } 4403 \\
\text { on a sieve of polyamide fabric No.45/50 PA }\end{array}$ & $\%$ & 3.0 & 10.0 & 3.0 & GOST $27560-87$ \\
\hline 8 & Drop number & with & 314 & 424 & 365 & GOST 27676-88 \\
\hline 9 & Mass fraction of ash in terms of dry matter & $\%$ & 0.47 & 0.55 & 0.62 & GOST 27494 \\
\hline 10 & Acid number of fat & $\mathrm{mg} \mathrm{KOH} / \mathrm{g}$ & 23.0 & 28.5 & 30.0 & GOST 31700 \\
\hline 11 & Acidity & Deg. & 2.0 & 2.0 & 2.3 & GOST 27493-87 \\
\hline
\end{tabular}


Ash content and whiteness are interrelated indicators of the quality of flour, since both characterize the degree of purification of flour from branded particles (outer layers of grain). As a result of the tests carried out, it was established that flour sample No.1 was characterized by a high whiteness index (62 CU of the device) and low ash content (0.47\%), flour sample No.3 had a high ash content value $(0.62 \%)$, which could be one of the reasons for obtaining dry, non-ductile dough and coarse structure of the finished product (Table 7 and Table 8).

All studied flour samples contain protein in an amount exceeding the optimum figure for sugar cookies: $11.5 \%, 11.7 \%$, $12.1 \%$, respectively. At the same time, the quality of gluten in flour sample No.3 is satisfactorily strong, the indicator of the mass fraction of raw gluten is $28 \%$, which increases the likelihood of the formation of a «prolonged» dough and the production of finished products with a hard and rough structure.

For the technological evaluation of wheat flour, not only the quantity, but also the quality of gluten is important, which is determined using an FDM device that characterizes the amount of compression deformation of raw gluten. Flour sample number 3 is characterized by a satisfactorily strong gluten, which is easily torn when stretched (FDM - 51 units of the device), such flour is poorly suited for making sugar cookies. In terms of quality, elastic properties, the gluten of flour in samples No.1 and No.2 belongs to the first group (FDM -65 units and 70 units of the device, respectively), which meets the requirements for flour for sugar cookies.

To obtain a wider range of information about the rheological properties of flour, the Brabender farinograph WP 810101 (Table 5) was used.

Rheological characteristics of wheat flour samples (Farinogram indicators)

\begin{tabular}{llcccc}
\hline No. & \multicolumn{1}{c}{ Indicator name } & UOM & \multicolumn{3}{c}{ VALUE } \\
\cline { 4 - 6 } & & & $\begin{array}{c}\text { Sample } \\
\text { No.1 }\end{array}$ & $\begin{array}{c}\text { Sample } \\
\text { No.2 }\end{array}$ & $\begin{array}{c}\text { Sample } \\
\text { No.3 }\end{array}$ \\
\hline 1 & Dough formation time & $\min$ & 3.0 & 4.0 & 4.5 \\
\hline 2 & Dough stability & $\min$ & 4.0 & 1.0 & 1.5 \\
\hline 3 & Dough consistence & $\min$ & 7.0 & 5.0 & 6.0 \\
\hline 4 & Water absorption capacity & $\%$ & 60.1 & 58.2 & 62.5 \\
\hline 5 & Extensibility & $\mathrm{cm}$ & 17 & 13 & 11 \\
\hline
\end{tabular}

Analysis of the obtained data revealed significant differences and allowed ranking wheat flour samples by quality:

$\square$ the consistency of the dough from flour sample No.1 is characterized by high stability (the duration of maintaining the maximum level of its consistency), consistence (the sum of the time it takes to form a dough and the time when it is stable) and extensibility.

$\square$ dough from flour sample No.3 has a maximum formation time (the period from the beginning of kneading until the formation of a homogeneous mass), high water absorption capacity $(62.5 \%)$ and low extensibility $(11 \mathrm{~cm})$ compared with the other samples. Based on the totality of the data obtained, it is possible to draw a preliminary conclusion that wheat flour sample No.3 was obtained from dry corn grain and is least suitable for use in the production of sugar cookies.

Unfortunately, at the present level of development of science in the confectionery industry, we are not sufficiently armed with methods for evaluating the technological properties of flour, which are necessary to produce sugar cookies with optimal characteristics, and the concept of «optimum properties of the dough» needs to be defined. Therefore, still a quick and effective way to identify the "optimal properties of the dough» is the method of laboratory test baking $[10,11]$.

For the differentiation of flour of different grade by the quality of finished products, standard recipes and technology were used. As a base, the recipe of sugar cookies No.103 was chosen [15], as the most typical representative of this group of products, both in composition and organoleptic properties. Cooking was carried out according to the current technological instructions [16] with the use of pre-kneaded palm oil as a fat component (Table 6 and Figure 3).

Table 6

Recipe ratio of the sugar cookies ingredients

\begin{tabular}{lcc}
$\begin{array}{c}\text { Name of raw materials and } \\
\text { semi-finished products }\end{array}$ & $\begin{array}{c}\text { Mass fraction of } \\
\text { dry substances, \% }\end{array}$ & $\begin{array}{c}\text { Raw material } \\
\text { consumption, kg }\end{array}$ \\
\hline Top-grade wheat flour & 85.50 & 62.00 \\
\hline Corn starch & 87.00 & 4.60 \\
\hline Powdered sugar & 99.85 & 15.00 \\
\hline Sand sugar & 99.85 & 3.00 \\
\hline Invert syrup & 70.00 & 2.50 \\
\hline Palm oil & 99.99 & 18.00 \\
Whole milk & 11.50 & 2.30 \\
\hline Melange & 27.00 & 3.00 \\
Salt & 96.50 & 0.4 \\
\hline Baking soda & 50.00 & 0.4 \\
Ammonium carbon salt & 0.00 & 0.3 \\
TOTAL: & - & 111.5 \\
OUTPUT: & 95.50 & 100.0
\end{tabular}

Estimated dough moisture - 16\%

The identity of the used recipe components, their ratios and technological parameters of preparation allows to substantiate the dependence of the physical and chemical as well as rheological properties of the dough on the technological properties of the flour used (Table 7).

Table 7

Rheological characteristics of dough for sugar cookies

\begin{tabular}{|c|c|c|c|}
\hline \multirow{2}{*}{ Indicator name } & \multicolumn{3}{|c|}{ Wheat flour } \\
\hline & Sample No.1 & Sample No.2 & Sample No.3 \\
\hline Kneading features & $\begin{array}{l}\text { The dough was kneaded well and evenly to } \\
\text { form a homogeneous, plastic mass forming } \\
\text { a non-disintegrating lump when squeezed, } \\
\text { there is no sticking of the dough on the walls } \\
\text { and blades of the kneader, the formation of } \\
\text { the dough lump took } 2 \text { minutes. }\end{array}$ & $\begin{array}{l}\text { The dough is loose, with the presence of a } \\
\text { local non-kneading flour mixed with the } \\
\text { formation of large agglomerates, there } \\
\text { is sticking of the dough on the walls and } \\
\text { blades of the kneader, the formation of a } \\
\text { dough lump took } 3 \text { minutes. }\end{array}$ & $\begin{array}{l}\text { The dough is dense, crumbling, clay-like, } \\
\text { significant sticking of the dough onto } \\
\text { the walls and blades of the kneader, } \\
\text { the formation of a dough lump took } 2.5 \\
\text { minutes. }\end{array}$ \\
\hline Molding features & $\begin{array}{l}\text { The dough is well and quickly rolled, forming } \\
\text { a uniform thickness layer with a flat smooth } \\
\text { surface. }\end{array}$ & $\begin{array}{l}\text { The dough was well rolled, forming a } \\
\text { uniform thickness layer with a smooth } \\
\text { surface with the presence of a small } \\
\text { number of cracks }\end{array}$ & $\begin{array}{l}\text { When rolling, the dough crumbled and } \\
\text { disintegrated, forming an uneven layer } \\
\text { with a large number of cracks on the } \\
\text { surface. }\end{array}$ \\
\hline Density, kg/m³ & 1170 & 1220 & 1300 \\
\hline Dough moisture, \% & 15.4 & 15.6 & 16.0 \\
\hline
\end{tabular}


Figure 3. Technological scheme of making sugar cookies

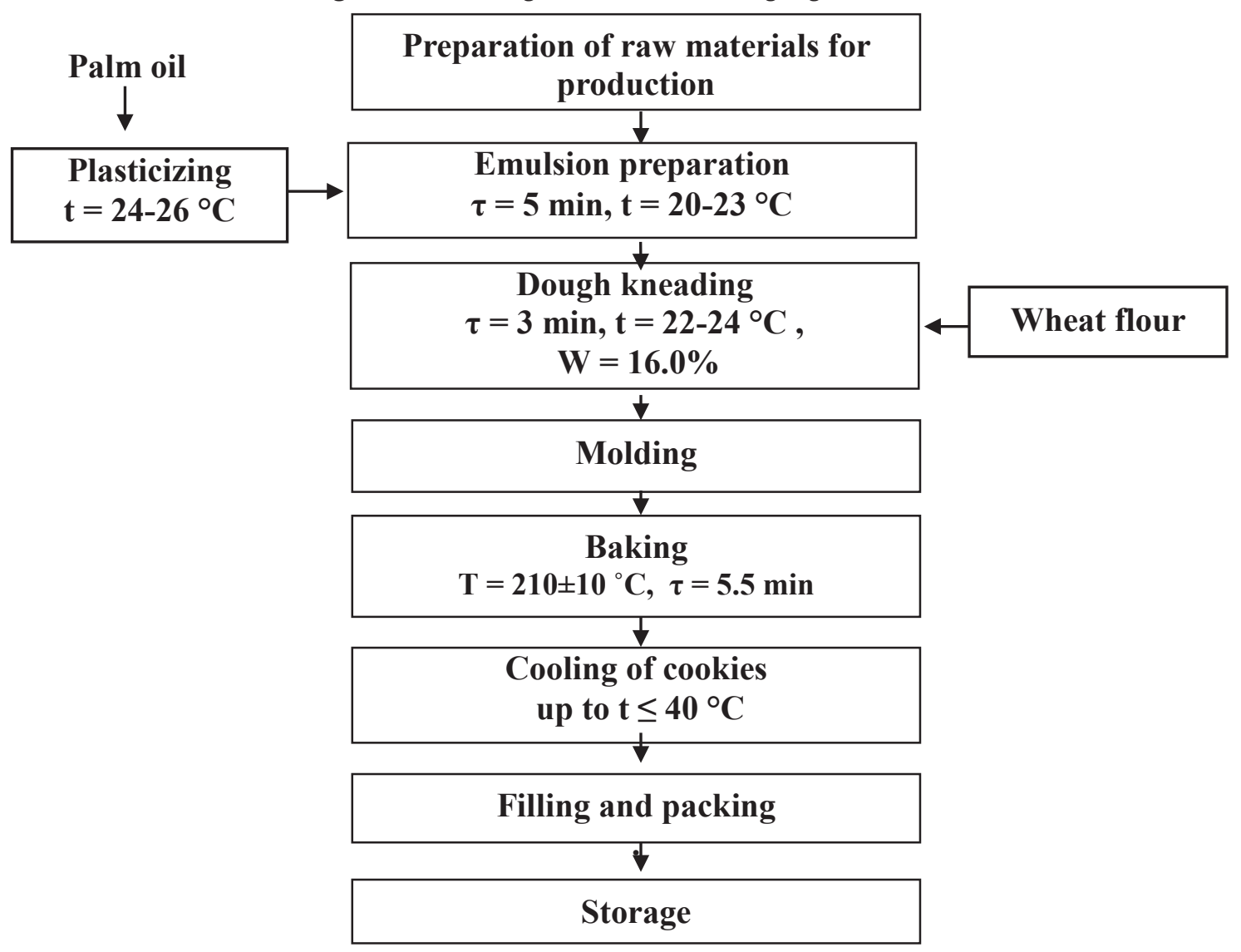

Immediately after making the dough, it was rolled out on an automated rolling machine into a layer $5 \mathrm{~mm}$ thick, molded with a metal notch of a round shape, baked on steel sheets and cooled in natural conditions to room temperature.

As a result of research on organoleptic and physical and chemical parameters of cookies, a similar nature of the relationship between the technological properties of flour, the rheological characteristics of the dough and the quality of the finished product were confirmed (Table 8 ).

The results of the organoleptic evaluation using a 45-point scale, taking into account the weighting factors of quality indicators and possible defects, are presented in Figure 4.

As a result of the analysis of the organoleptic characteristics of products, it was established that sample No.1 is characterized by the maximum number of points -43.5 . Number of points for cookies sample No.2-41.8 sample No.3-39.5.

\section{Conclusion}

The conducted studies allowed substantiating the following indicators as the defining characteristics of the quality of wheat flour for sugar cookies: ash content, quantity and quality of gluten together with the rheological properties of the dough (in terms of farinogram).

High correlation of these indicators with the results of laboratory test baking was noted, which, in turn, allows evaluating the technological properties of flour and predicting the quality of finished products with a high degree of accuracy.

Inclusion of these indicators in the specification for wheat flour will allow more efficient use of grain resources, increase the efficiency of control of raw materials, simplify production and stabilize the quality of sugar cookies.

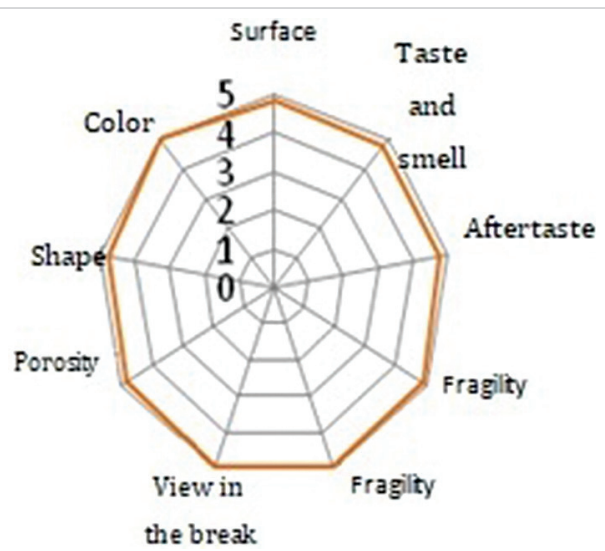

Sample No.1

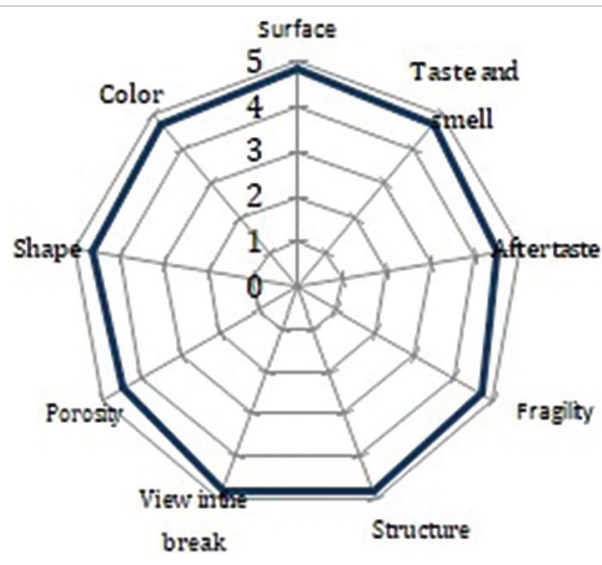

Sample No.2

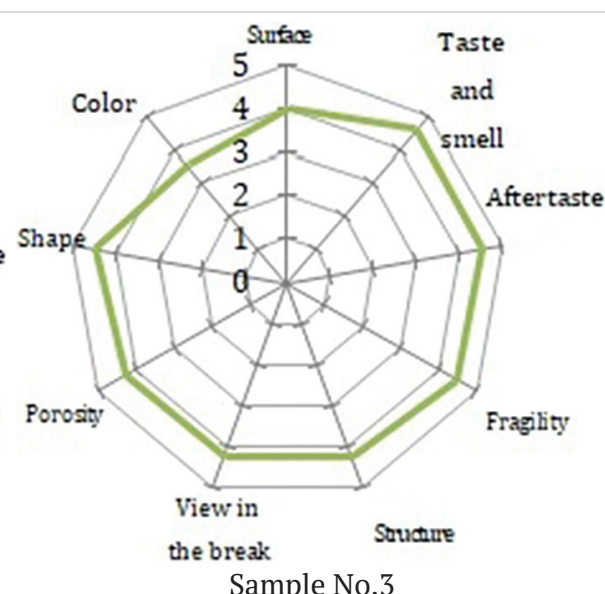

Sample No.3

Figure 4. Profilograms of organoleptic assessment of sugar cookies 
Quality indicators of sugar cookies

Table 8

\begin{tabular}{|c|c|c|c|}
\hline \multirow{2}{*}{ Indicator name } & \multicolumn{3}{|c|}{ VALUE } \\
\hline & Sample No.1 & Sample No.2 & Sample No.3 \\
\hline \multicolumn{4}{|c|}{ Organoleptic indicators } \\
\hline Form & $\begin{array}{l}\text { Proper, without dents and blisters. } \\
\text { Rounded, flat }\end{array}$ & Improper, strapped, lens-shaped & Improper, strapped \\
\hline Surface & $\begin{array}{l}\text { Even, smooth, no blistering. } \\
\text { With single inclusions of undissolved } \\
\text { sugar crystals. } \\
\text { The bottom surface is flat. }\end{array}$ & $\begin{array}{l}\text { Uneven, wrinkled, with slight swellings. } \\
\text { With inclusions of undissolved sugar crystals. } \\
\text { On the bottom surface there are hollows in } \\
\text { the form of sinks with an area of } 10-15 \mathrm{~mm}^{2}\end{array}$ & $\begin{array}{l}\text { Uneven, rough, with slight swellings. } \\
\text { With inclusions of undissolved sugar crystals. } \\
\text { On the bottom surface there are hollows in } \\
\text { the form of sinks with an area of } 5-10 \mathrm{~mm}^{2}\end{array}$ \\
\hline Color & Uniform, straw golden & $\begin{array}{l}\text { Straw with a large number of dark-colored } \\
\text { (brown) inclusions up to } 1 \mathrm{~mm}\end{array}$ & $\begin{array}{l}\text { Straw with a large number of dark-colored } \\
\text { (brown) inclusions up to } 1 \mathrm{~mm}\end{array}$ \\
\hline Section view & $\begin{array}{l}\text { Baked cookies with a uniform structure } \\
\text { and developed porosity, without voids } \\
\text { and traces of underkneading }\end{array}$ & $\begin{array}{l}\text { Baked cookies with a uniform finely porous } \\
\text { structure, without voids and no traces } \\
\text { of the dough unmixed }\end{array}$ & $\begin{array}{l}\text { Baked cookies with a porous structure somewhat } \\
\text { condensed in the center of the product, without } \\
\text { voids and no traces of the dough unmixed }\end{array}$ \\
\hline Taste and smell & $\begin{array}{l}\text { Expressed, rich, without foreign taste } \\
\text { and smell }\end{array}$ & $\begin{array}{l}\text { Less expressed, flat, without foreign taste } \\
\text { and smell. }\end{array}$ & $\begin{array}{l}\text { Less expressed, flat with mealy aftertaste. } \\
\text { No foreign smell. }\end{array}$ \\
\hline Texture & $\begin{array}{l}\text { Gentle, dry, friable, quickly dissolving } \\
\text { when chewed }\end{array}$ & $\begin{array}{l}\text { More dense, friable, dissolves well when } \\
\text { chewed }\end{array}$ & More dense, lumpy when chewed, sticky \\
\hline \multicolumn{4}{|c|}{ Physical and chemical indicators } \\
\hline Moisture, \% & 6.1 & 5.9 & 5.9 \\
\hline Water activity & 0.357 & 0.382 & 0.423 \\
\hline Wettability, \% & 208 & 213 & 195 \\
\hline Strength, $\mathrm{kPa}$ & 4.7 & 5.4 & 5.3 \\
\hline Density, $\mathrm{kg} / \mathrm{m}^{3}$ & 490 & 504 & 548 \\
\hline
\end{tabular}

\section{Geometric specifications}

Products are round, but somewhat elliptical in shape, which may be due to rolling the dough in one direction (without turning)

\begin{tabular}{|c|c|c|c|}
\hline Diameter, mm & $\begin{array}{l}48.4-50.0(1.6) \\
50.0-51.5(1.5) \\
49.9-51.5(1.6)\end{array}$ & $\begin{array}{l}48.4-50.8(2.4) \\
49.0-51.9(2.9) \\
48.5-50.8(2.3)\end{array}$ & $\begin{array}{l}48.8-50.3(1.5) \\
47.4-49.6(2.2) \\
48.0-50.3(2.3)\end{array}$ \\
\hline Height, mm & $\begin{array}{l}7.5 \\
7.4 \\
7.4\end{array}$ & $\begin{array}{l}7.0 \\
7.7 \\
7.5\end{array}$ & $\begin{array}{l}8.0 \\
7.0 \\
7.7\end{array}$ \\
\hline $\begin{array}{l}\text { Height of } 10 \text { products } \\
\text { stacked in pile, mm }\end{array}$ & 73.1 & 76.2 & 79.2 \\
\hline
\end{tabular}

\section{Pictures}

View from above

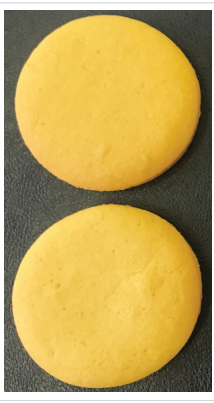

Side view

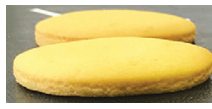

View from the bottom surface

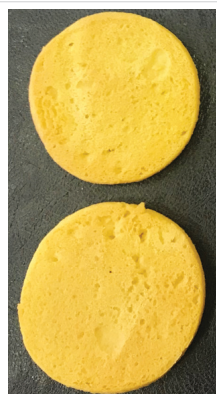

Section view

View on the edge of 10 pieces
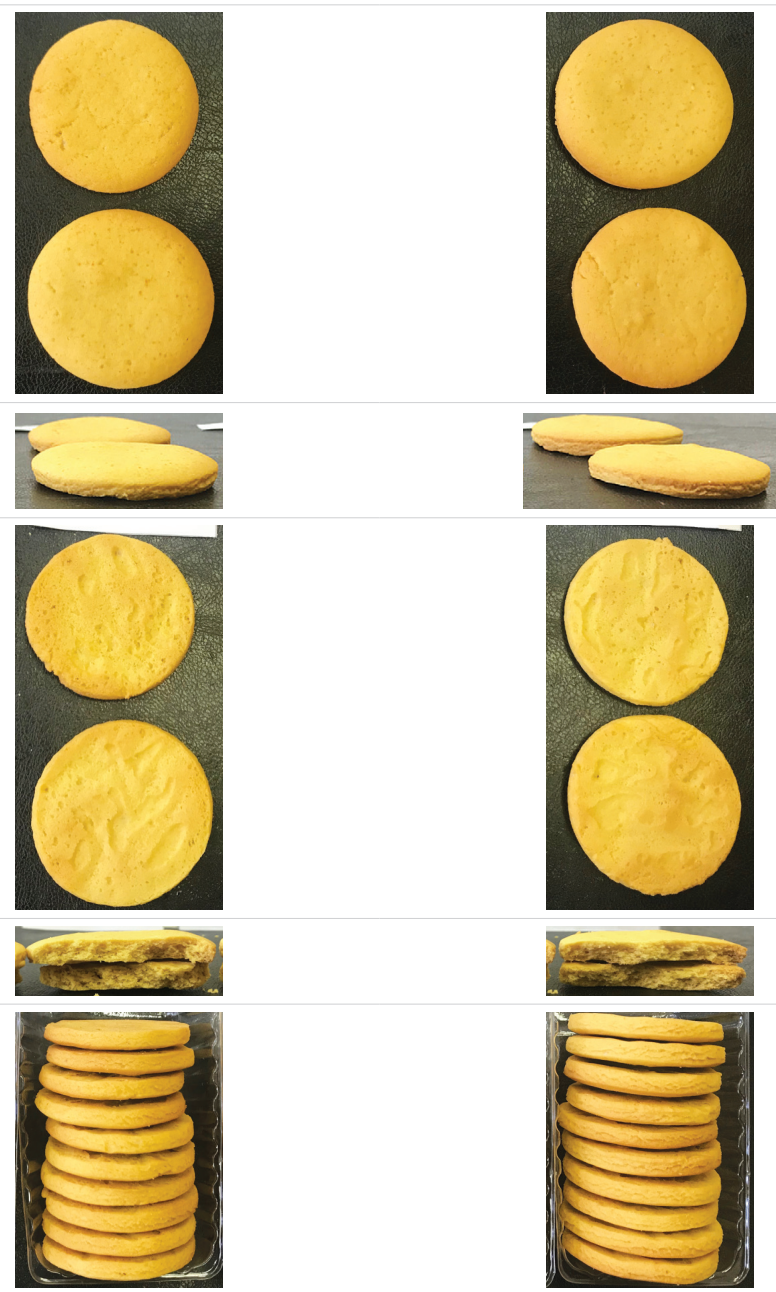


\section{REFERENCES}

1. Yanukovych, F. Confectionery Market in Russia shows stable growth [Electronic resource: http://www.indexbox.ru/news/rynok-konditerskih-izdelij-v-rossii-pokazyvaet-stabilnyj-rost. Access date 07.08.2018] (in Russian)

2. Tarasenko, N. A., Baranova, Z. A. (2015). Market researches of consumer motivations and preferences at the choice of confectionery. Fundamental research, 9-1. 174-177. (in Russian)

3. Nikitina, E. (2018). Confectionery market of Russia - recovery after the crisis. Hlebopekarnyj \& Konditerskij Forum, 34. 44-45. (in Russian)

4. Makarenko, P. (2019). Sweet life will not become a habit. Sfera: confectionery and bakery industry, 2(79), 6. (in Russian)

5. Ivanova, V. N., Seregin, S. N. (2014). Food industry of Russia. Current state, problems, guidelines for future development. M, Finance and Statistics. - 568 p. ISBN 978-5-279-03546-5. (in Russian)

6. Glinskiy, V.V., Serga, L.K., Samotoy, N.V., Simonova, E.Yu. (2017). The development of the food industry as a condition for improving Russia's national security. Vestnik NSUEM, 3. 221-234. (in Russian)

7. Manley, D. (2003) Technology of biscuits, crackers and cookies. SPb, Professiya. - 558 p. ISBN 5-93913-046-1. (in Russian)

8. Kilcast, D., Subramaniam, P. (2012). Food and beverage stability and shelf life. Bakery confectionery products. SPb, Professiya. - 441 p. ISBN $978-$ 5-904757-38-0. (in Russian)

9. Soldatova, E. A., Mistenyova, S. Yu., Savenkova, T. V. (2015). Specifications for raw materials as an integral part of product quality managemen Confectionery production, 1, 14-16. (in Russian)

10. Meleshkina, E. P., Cheskidova, A. S., Koval, A. I., Kirillova, E. V. (2018). Wheat flour as a raw material for confectionery production: development of a method for assessing the quality of wafers and study the effect of rheological properties of the test on the quality of the alveograph wafers. Materials of the Business conference «Cakes. Waffles. Cookie. Gingerbreads», 59-64. (in Russian)

11. Khvostenko, E. V. (2015). Improving the technology of flour confectionery products based on waxy wheat flour. Dissertation for the scientific degree of Candidate of Technical Sciences. Odessa. - 253 p. (in Ukraine)

12. Savenkova T. V., Soldatova E. A., Taleisnik M. A. (2017) Requirements for flour as an integral part of the quality management of flour confectionery products. Sfera: confectionery and bakery industry, 4 (71), 56-61. (in Russian)

13. Coven, S. P., Young, S. L. (2011). Additional recommendations for bakers and confectioners. Another 151 question and answer. SPb, Professiya. 246 p. ISBN 978-5-904757-11-3. (in Russian)

14. Coven, S. P., Young, S. L. (2006). Practical recommendations for bakers and confectioners. 202 questions and answers. SPb, Professiya. $-238 \mathrm{p}$. ISBN 978-5-93913-099-2. (in Russian)

15. Collection «Recipes for cookies». (1987). M., All-Union research Institute of the confectionery industry. -247 p. (in Russian)

16. Collection of «Technological instructions for the production of flour confectionery» (1992). [Ed.: Bernshtejn T.S. i dr.]. M., All-Union research Institute of the confectionery industry. -240 p. (in Russian).

17. Gakova, A. O. (2012). Rheology of raw materials, semi-finished products and preparations of bakery, confectionery and pasta production. Educational and methodical complex of discipline. M, MGUTU. - 171 p. (in Russian)

18. Hosni, R. K. (2006). Grain and grain processing. SPb, Professiya. - 330 p ISBN5-93913-085-2. (in Russian)

19. Comparison of quality standards for wheat in Russia and the United States (Material provided by the American wheat Association). Information company ProAgro Grup. [Electronic resource: http://www.proagro. com.ua/reference/standard/usstand/11020.html Access date 01.2019] (in Russian)

20. Commodity classification of wheat in the United States and Russia (based on the American wheat Association). [Electronic resource: Agrovestnik / https://agrovesti.net/lib/tech/growing-cereals/tovarnye-klassifikatsiipshenitsy-v-ssha-i-rossii.html /Access date 22.10.2015]

21. Meleshkina, E. P. (2016). On new approaches to the quality of wheat flour. Production Quality Control, 11.13-18. (in Russian)

22. Meleshkina, E. P. (2018). On the need for the production of wheat grainimprover. Bakery products, 12, 18-20. (in Russian)

23. Soldatova, E. A., Savenkova, T. V. Mistenyova, S. Yu. (2019). The influence of wheat flour on the quality and manufacturability of the wafer sheet. Materials of the international scientific and practical conference dedicated to the 90th anniversary of VNIIZ, 343-347. ISBN 978-5-901768-5-6 (in Russian)

\section{AUTHOR INFORMATION}

Tatyana V. Savenkova - doctor of technical sciences, professor, Director, All-Russian Scientific Research Institute of Confectionery Industry - Branch of V.M. Gorbatov Federal Research Center for Food Systems of RAS, 107023, Moscow, Electrozavodskaya Str, 20, bld. 3, Tel.: +7-495-963-64-09, e-mail: conditerprom@mail.ru

Elena A. Soldatova - candidate of technical sciences, leading researcher, laboratory technology of production of flour confectionery products, All-Russian Scientific Research Institute of Confectionery Industry - Branch of V.M. Gorbatov Federal Research Center for Food Systems of RAS, 107023, Moscow, Electrozavodskaya Str, 20, bld. 3, Tel.: +7-495-962-17-35, e-mail: confect@ya.ru

* corresponding author

Svetlana Yu. Misteneva - graduate student, All-Russian Scientific Research Institute of Confectionery Industry - Branch of V.M. Gorbatov Federal Research Center for Food Systems of RAS, 107023, Moscow, Electrozavodskaya Str, 20, bld. 3, Tel.: +7-495-962-17-35, e-mail: mki.niikp@mail.ru

Mikhail A. Taleysnik - candidate of technical sciences, leading researcher, laboratory technology of production of flour confectionery products, All-Russian Scientific Research Institute of Confectionery Industry - Branch of V.M. Gorbatov Federal Research Center for Food Systems of RAS, 107023, Moscow, Electrozavodskaya Str, 20, bld. 3, Tel.: +7-495-962-17-35, e-mail: mki.niikp@mail.ru

Authors are equally relevant to the writing of the manuscript, and equally responsible for plagiarism

The authors declare no conflict of interest

Received 23.04.2019 Accepted in revised 16.05.2019 Accepted for publication 11.06.2019 